\title{
OBITUARY
}

\section{Edward (Eamon) T. Hanrahan}

Eamon Hanrahan enjoyed a long and productive lifespan of 95 years, during which he made an important contribution to the development of geotechnical engineering education and practice in Ireland. He was born in Limerick city in 1917, where he attended local primary and secondary schools. He studied engineering at University College Dublin (UCD) and was awarded the BE degree in Civil Engineering in 1939. He worked in England in the 1940s and returned to take up a post at UCD in 1948, where he remained until his retirement in 1987.

Imbued with an enquiring and creative mind, Eamon pursued his keen interest in soil mechanics and related foundation engineering practice from his earliest days as a young engineer. At the time he was a schoolboy it was customary to refer to schoolchildren as scholars. For Eamon, this was a designation that remained apt throughout his life, as he pursued advancement of knowledge in his chosen field of study with a creative energy and remarkable insight. Already, as a very young engineer, he was awarded the ME degree in 1946, with a thesis based on his early professional practice immediately following graduation. He was awarded a PhD in 1954 and a DSc in 1983.

He was held in the highest regard, both personally and professionally, by generations of undergraduate and postgraduate civil engineering students and staff colleagues in UCD. Not only was he a dedicated teacher and wise mentor, but his creative instincts and infectious enthusiasm for his subject also combined to develop a highly regarded centre of expertise in geotechnical engineering. He presented the first postgraduate course in soil mechanics for practicing Irish engineers in 1955.

$\mathrm{He}$ initiated and sustained an active and productive research programme on the mechanical properties and deformation characteristics of soft soils, with a particular focus on peat. In economically difficult circumstances, he developed laboratory facilities that underpinned his research, the findings of which he published widely in national and international journals. This work is perhaps best exemplified by his 1954 and 1964 Géotechnique papers (Hanrahan, 1954, 1964), which are still regularly cited. His highly original treatise on the analysis of soil behaviour under applied loading, entitled The Geotechnics of Real Materials: The $e_{g}, e_{k}$ Method, was published by Elsevier in 1985 . Although best known for his work on peat and soft soils, he made significant contributions to the understanding of the behaviour of glacial tills, as demonstrated in his 1977 report to An Foras Forbartha.

Despite his achievement of professional distinction, Eamon remained a man of innate modesty with a wide

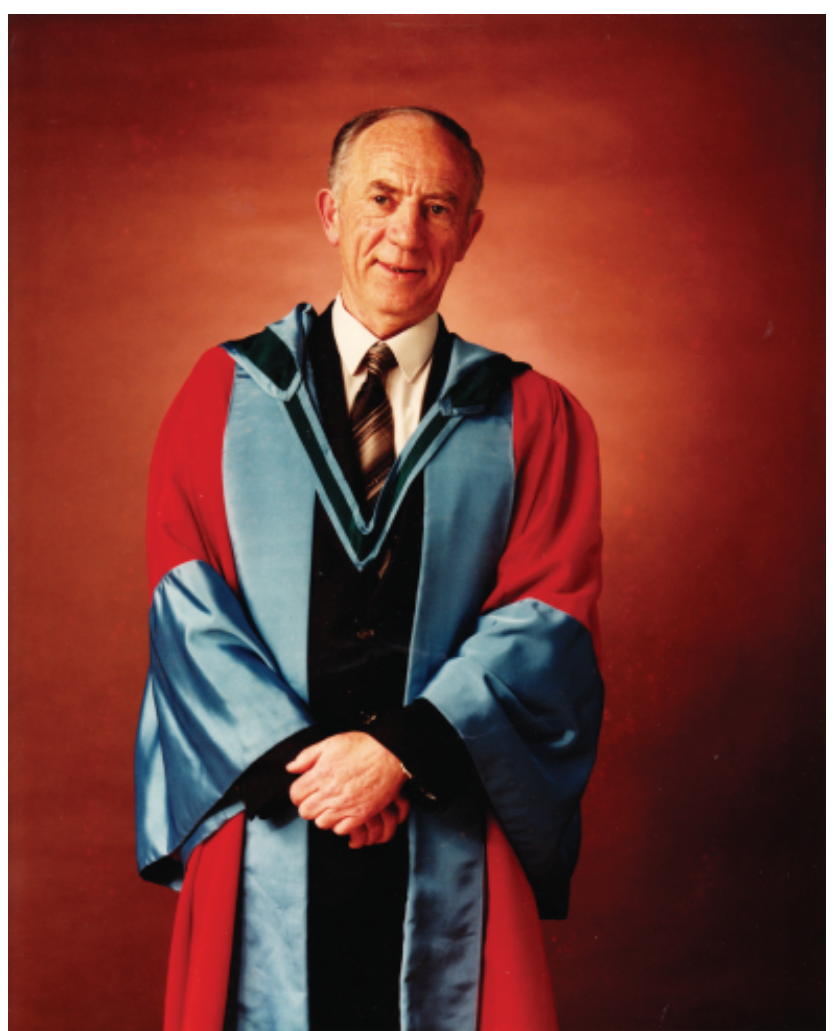

Professor Edward T. Hanrahan (1917-2012)

range of interests. He loved the Irish language, Gaelic games and regularly took summer holidays in the Gaelic-speaking area of Ireland with his family. He was a keen gardener and loved music. His kind and compassionate nature was exemplified by his lifelong membership of the St Vincent de Paul Society, which is dedicated to the poor.

Tom J. Casey, Aquavarra Ltd, formerly

University College Dublin

Michael Long, University College Dublin

\section{REFERENCES}

Hanrahan, E. T. (1954). An investigation of physical properties of peat. Géotechnique 4, No. 3, 108-121, http://dx.doi.org/10.1680/ geot.1954.4.3.108.

Hanrahan, E. T. (1964). A road failure on peat. Géotechnique 14, No. 3, 185-202, http://dx.doi.org/10.1680/geot.1964.14.3.185. 